\title{
JĘZYKI INFORMACYJNO-WYSZUKIWAWCZE W KATALOGACH OPAC BIBLIOTEK PAŃSTWOWYCH WYŻSZYCH SZKÓŁ ZAWODOWYCH
}

\author{
Katarzyna Cyran \\ Biblioteka Państwowej Szkoły Wyższej \\ im. Papieża Jana Pawła II \\ w Białej Podlaskiej
}

Język informacyjno-wyszukiwawczy, wyszukiwanie informacji, użytkownicy informacji, Język Haseł Przedmiotowych BN, język słów kluczowych, biblioteki akademickie, biblioteki PWSZ

\section{Wprowadzenie}

Wyspecjalizowane, sztuczne systemyjęzykowe wykorzystywane do opisu treści i podstawowych cech formalnych dokumentów określa się mianem języków informacyjno-wyszukiwawczych (JIW). Istnieje wiele tego typu języków, sformułowano wiele ich definicji. Najczęściej przyjmuje się, że język informacyjno-wyszukiwawczy to sztuczny, czyli celowo zbudowany system językowy, składający się z określonego zbioru znaków i reguł posługiwania się nimi, specjalizujący się w opisywaniu cech treściowych i formalnych dokumentów oraz umożliwianiu wyszukiwania dokumentów o określonych cechach na podstawie uprzednio przygotowanych charakterystyk ${ }^{1}$.

Jadwiga Woźniak-Kasperek podaje, iż dobry język informacyjno-wyszukiwawczy powinien:

- zawierać pojęcia służące takiemu opisowi dokumentów, by użytkownik bez problemu uzyskał odpowiedź na formułowane zapytania (innymi słowy język informacyjno-wyszukiwawczy winien cechować wystarczająco szeroki zakres słownictwa o dostatecznej szczegółowości);

- charakteryzować się poprawnym i właściwym paradygmatem;

- być jednoznaczny i niesynonimiczny;

- być stosunkowo łatwo przyswajalny przez bibliotekarzy i w pewnym stopniu przez użytkowników (im większy jest stopień samodzielności wyszukiwawczej użytkowników - z tym zjawiskiem mamy do czynienia w systemach zautomatyzowanych, dostępnych w sieciach - tym większa waga tego postulatu);

${ }^{1}$ B. Sosińska-Kalata: Podręcznik UKD [Uniwersalnej Klasyfikacji Dziesiętnej] dla bibliotekarzy i pracowników informacji. Warszawa 1995, s. 24. 
- odpowiadać warunkom technicznym i finansowym biblioteki².

Język informacyjno-wyszukiwawczy, w którym są opracowywane dokumenty, winien być narzędziem sprawnym i przyjaznym użytkownikowi. Projektując lub udoskonalając JIW, należy pamiętać o jego satysfakcji wynikającej z otrzymania relewantnych odpowiedzi na postawione zapytanie, stanowi ona bowiem o sukcesie biblioteki.

Proces opracowania rzeczowego dzieli się zwykle na pięć etapów: 1) analizę dokumentu, 2) streszczenie wyników analizy, 3) redukcję i selekcję informacji, 4) tworzenie charakterystyki słownej, 5) przekład charakterystyki słownej na JIW. Ważny jest trzeci etap redukowania i selekcji informacji uzyskanych w wyniku analizy. Wskazanie jednego przedmiotu głównego może prowadzić do utraty informacji, które dotyczą przedmiotów pobocznych, mała selekcja z kolei może być przyczyną szumu informacyjnego, obniżającego kompletność i dokładność wyszukiwania. Szerokość indeksowania, określająca zakres, w jakim charakterystyka odwzorowuje informacje zawarte w dokumencie, powinna być ustalana indywidualnie dla poszczególnych systemów informacyjno-wyszukiwawczych i uwzględniać oczekiwania użytkowników³.

Współczesny użytkownik, tzw. end-user, coraz częściej sam, bez pośrednictwa bibliotekarza, wyszukuje potrzebne mu informacje. Stąd często postuluje się, że JIW należy dostosowywać do jego oczekiwań i umiejętności. JIW, którym samodzielnie posługuje się użytkownik, nie może być skomplikowany, powinien być prosty i zrozumiały. W przypadku języków haseł przedmiotowych (JHP), w których stosuje się notację paranaturalna, konieczne jest zapewnienie, aby sens wyrażeń użytych jako tematy i określniki nie odbiegał daleko od ich znaczeń w odpowiednim języku naturalnym, a hasła przedmiotowe nie były zbyt rozbudowane. Nadmierna sztuczność słownictwa i duża liczba określników w haśle przedmiotowym powoduje, że użytkownicy szybko się zniechęcają i decydują się na wyszukiwanie za pomocą słów kluczowych.

University College London na zlecenie Joint Information System Committee (JISC) bibliotek brytyjskich przeprowadził badania (Information behaviour of the researcher of the future), których celem było ustalenie tendencji w sposobach wyszukiwania informacji przez „pokolenie Google” (ang. Google generation, urodzeni po 1993 r.) oraz określenie modelu interakcji z elektronicznymi zasobami informacyjnymi. Oczekiwano, iż ich wyniki pozwolą bibliotekom lepiej przygotować się do spełniania oczekiwań użytkowników, te jednak zaskakuja. Okazało się, że 89\% uczniów rozpoczyna wyszukiwanie informacji w Internecie (w tym tylko $2 \%$ wybiera stronę internetową biblioteki), a 93\% jest zadowolona z wyników wyszukiwań prowadzonych za pomoca wyszukiwarki internetowej. Wyszukiwarki internetowe cieszą się popularnością wśród uczniów, są dla nich bardziej atrakcyjne niż tradycyjne lub elektroniczne katalogi biblioteczne ${ }^{4}$. Bi-

2 J. Woźniak-Kasperek: Tendencje w teorii i praktyce języków informacyjno-wyszukiwawczych. W: Opracowanie przedmiotowe - osiągnięcia naukowe i praktyka. Warsztaty: 31.03-1.04.2004. Warszawa 2004, s. 8.

${ }^{3}$ Ibidem, s. 15.

${ }^{4} \mathrm{E}$. Rozkosz: Information behaviour of the researcher of the future. ISBNnik: informator Sekcji Bibliotek Niepaństwowych Szkół Wyższych przy Zarządzie Głównym Stowarzyszenia Bibliotekarzy Polskich. 2010, z. 21(111), s. 3 [online]. 
bliotekarze muszą więc podjąć działania, które spowoduja, że katalogi będą dla młodych ludzi równie ważnym źródłem informacji jak wyszukiwarka internetowa. Opisy księgozbiorów naukowych znajdujące się w katalogach OPAC powinny być precyzyjne i spójne. Zadaniem biblioteki jest weryfikowanie, czy informacja odpowiada potrzebom użytkownika. Ponadto biblioteka musi dysponować dziś nie tylko informacją aktualna, ale i szybko dostępna, w przeciwnym razie użytkownik zerwie z nią kontakt, przejdzie do szarej strefy nieużytkowników, stanie się tzw. non-user.

\section{Języki informacyjno-wyszukiwawcze stosowane w bibliotekach państwowych wyższych szkół zawodowych}

Udostępnianie informacji o kolekcjach bibliotecznych w Internecie wymaga zastanowienia się, które elementy dotychczasowej pracy związanej z indeksowaniem sprawdzają się w tym środowisku, a które należy wyeliminować. Według Woźniak-Kasperek, odnosząc się tylko do JIW, należałoby:

- opracować strategię upraszczania, czyli niemechanicznego eliminowania poszczególnych reguł, systemów gramatycznych JIW przy zachowaniu kontroli słownictwa;

- uczynić słowniki JIW aktywnymi elementami procesu wyszukiwania (do tej pory aktywność leży jedynie po stronie użytkownika wyszukującego informacje), dającymi użytkownikowi możliwość wyboru i pozwalającymi określić zasady postępowania;

- zmienić sposób prezentacji słownika JIW na graficzny, z perspektywa przejścia w kierunku map wiedzy;

- powrócić do praktyki dołączania abstraktów do opisów bibliograficznych i treściowych dokumentów (wykonanych w sztucznym języku informacyjnym)5.

Upraszczaniem JIW zajmuja się ośrodki tworzące kartoteki wzorcowe. W przypadku Języka Haseł Przedmiotowych Biblioteki Narodowej (JHP BN) jest nim Biblioteka Narodowa, za Język Haseł Przedmiotowych KABA (JHP KABA) odpowiada Centrum Narodowego Uniwersalnego Katalogu Centralnego (NUKAT). W omówionym w moim artykule badaniu próbowano ustalić co może i powinien zrobić bibliotekarz zajmujący się opracowaniem zbiorów w swojej bibliotece, by ułatwić użytkownikom wyszukiwanie informacji, a przez to podnieść jakość usług świadczonych przez tę bibliotekę.

W marcu 2010 r. skontaktowano się droga elektroniczną z 36 bibliotekami państwowych wyższych szkół zawodowych ${ }^{6}$ (MENiS, 2010). Skierowano do nich pytanie dotyczące JIW, w których opracowuja one swoje

${ }^{5}$ J. Woźniak-Kasperek: Języki informacyjne: między tradycją a nadzieją na cyfrową przyszłość. „Przegląd Biblioteczny” 2010, z. 1, s. 16.

${ }^{6}$ MENiS: Wykaz Państwowych Wyższych Szkół Zawodowych. Ministerstwo Edukacji Narodowej i Sportu. [online]. [dostęp: 22.03.2010]. Dostępny w World Wide Web: <http:// www.nauka.gov.pl/szkolnictwo-wyzsze/system-szkolnictwa-wyzszego/uczelnie/uczelnie-publiczne/wykaz-uczelni-publicznych-nadzorowanych-przez-ministra-wlasciwego-dsszkolnictwa-wyzszego/panstwowe-wyzsze-szkoly-zawodowe>. 
zbiory. Odpowiedzi udzieliło 25 bibliotek $^{7}$. Wyniki badania zaprezentowano w tabeli 1.

Tabela 1

Języki informacyjno-wyszukiwawcze stosowane do opracowywania zbiorów bibliotek państwowych wyższych szkół zawodowych

\begin{tabular}{|l|c|c|c|c|}
\hline Język informacyjno-wyszukiwawczy & JSK & JHP KABA & JHP BN & $\begin{array}{c}\text { JHP KABA } \\
\text { i JHP BN }\end{array}$ \\
\hline Liczba bibliotek stosujących dane JIW & 2 & 3 & 18 & 2 \\
\hline Wyliczenie procentowe & $8 \%$ & $12 \%$ & $78 \%$ & $8 \%$ \\
\hline
\end{tabular}

Jak widać, w bibliotekach PWSZ najczęściej stosowany jest JHP BN (18 na 25 bibliotek). Jest to język kontrolowany kartoteką wzorcową, co częściowo zwalnia bibliotekarzy z odpowiedzialności za wykorzystywane słownictwo. Mimo iż JHP BN dąży do dużej szczegółowości, to nie zawsze uwzględnia zmiany zachodzące w słownictwie specjalistycznym, istotne przy opisie księgozbiorów bibliotek szkół wyższych. JHP BN jest językiem uniwersalnym, w którym dokumenty indeksowane są na wysokim poziomie ogólności. Przykład opisu Przewodnika po etyce w JHP BN, zaczerpnięty z katalogu Biblioteki Państwowej Szkoły Wyższej im. Papieża Jana Pawła II w Białej Podlaskiej (PSW w Białej Podlaskiej), dobrze ilustruje tę regułę:

Przewodnik po etyce / Singer, Peter (red.), Górnicka, Joanna (red. wyd. pol.) - Wyd. 2 . - Warszawa: Książka i Wiedza, 2002.

Opis rzeczowy publikacji proponowany przez Bibliotekę Narodową:

Etyka - historia - podręcznik.

Po wprowadzeniu zmian:

Etyka - historia.

Podręczniki.

Książka, której opis przytoczono powyżej, dotyczy problemów etyki społecznej, etyki chrześcijańskiej, hinduizmu, buddyzmu, islamu, ubóstwa, ekologii, eutanazji, aborcji itp., co nie znalazło odzwierciedlenia w opisie rzeczowym w JHP BN, a może być istotne dla użytkowników biblioteki uczelnianej.

Biblioteka PSW w Białej Podlaskiej ma stosunkowo niewielki księgozbiór. Zbiory opracowywane sa tu tylko w oparciu o hasła przedmiotowe przejmowane za pośrednictwem protokołu Z39.50 z Biblioteki Narodowej. Użytkownik, który przeszukuje katalog dokumentów zwartych tej biblioteki, nie znajdzie w nim informacji o książkach zawierających informacje na temat buddyzmu. Zasto-

${ }^{7}$ Biblioteki PWSZ, które wzięły udział w badaniu: PWSZ w Nowym Sączu, PWSZ w Elblagu, PWSZ we Włocławku, PWSZ im. Angelusa Silesiusa w Wałbrzychu, PWSZ im. Jana Amosa Komeńskiego w Lesznie, PWSZ w Koninie, PWSZ w Krośnie, PWSZ im. Papieża Jana Pawła II w Białej Podlaskiej, PWSZ w Chełmie, PWSZ w Płocku, PWSZ w Tarnowie, PWSZ im. Stanisława Staszica w Pile, PWSZ w Raciborzu, PWSZ w Zamościu, PWSZ w Gnieźnie, PWSZ w Oświęcimiu, PWSZ w Sulechowie, PWSZ im. prof. Stanisława Tarnowskiego w Tarnobrzegu, PWSZ w Głogowie, PWSZ w Suwałkach, PWSZ im. Bronisława Markiewicza w Jarosławiu, PWSZ im. Jana Grodka w Sanoku, PWSZ w Skierniewicach, Podhalańska PWSZ w Nysie, PWSZ w Gorzowie Wielkopolskim. 
sowanie bardziej szczegółowego opracowania zbiorów umożliwiłoby mu odnalezienie ich w posiadanej przez bibliotekę książce, m.in. o etyce w buddyzmie.

Jedna z bibliotek PWSZ proponuje wprowadzenie następujących zmian do opisu wspomnianej wyżej pozycji:

\begin{tabular}{|c|c|c|}
\hline $\begin{array}{l}\text { Etyka - szkice } \\
\text { Etyka chrześcijańska } \\
\text { Buddyzm - etyka } \\
\text { Filozofia }\end{array}$ & $\begin{array}{l}\text { Etyka - historia } \\
\text { Indie - etyka } \\
\text { Żydzi - etyka } \\
\text { Ubóstwo - etyka }\end{array}$ & $\begin{array}{l}\text { Etyka społeczna } \\
\text { Hinduizm - etyka } \\
\text { Islam - etyka } \\
\text { Ekologia - etyka }\end{array}$ \\
\hline Eutanazja - etyka & $\begin{array}{l}\text { Poronienie } \\
\text { sztuczne - etyka }\end{array}$ & $\begin{array}{l}\text { Stosunki } \\
\text { interpersonalne - etyka }\end{array}$ \\
\hline $\begin{array}{l}\text { tyka biznesu } \\
\text { okój - etyka }\end{array}$ & $\begin{array}{l}\text { Zwierzęta - etyka } \\
\text { Przestepstwo - etyka }\end{array}$ & $\begin{array}{l}\text { Wojna - etyka } \\
\text { Ewolucja - a etyka }\end{array}$ \\
\hline
\end{tabular}

Wszystkie zaproponowane hasła są zgodne z metodyka i słownictwem stosowanym w JHP BN, a indeksowanie zostało lepiej dostosowane do potrzeb biblioteki ${ }^{8}$.

Tylko trzy z 25 poddanych badaniu bibliotek PWSZ stosuja do opracowywania swoich zbiorów JHP KABA. W Polsce ten język jest wykorzystywany w większości bibliotek akademickich. Struktura słownictwa JHP KABA jest dostosowana do katalogowania przedmiotowego wyszczególniającego, katalogowania wyspecjalizowanych zagadnień jednostkowych często występujących w literaturze fachowej. Konstrukcje haseł przedmiotowych rozwiniętych z zastosowaniem określnika związanego pozwalają na dokładne i adekwatne katalogowanie. Zaletą JHP KABA jest jego kompatybilność $z$ dwoma najbardziej rozpowszechnionymi w świecie językami haseł przedmiotowych, RAMEAU i LCSH, co może mieć duże znaczenie dla polskich bibliotek zamierzających dokonywać wymiany danych bibliograficznych w ramach różnych projektów międzynarodowych ${ }^{9}$.

Do opracowania rozpatrywanej wcześniej ksiażki Przewodnik po etyce Centrum NUKAT proponuje użycie hasła: Etyka. Ten sposób opracowania sprawdza się w bibliotekach dużych ośrodków akademickich, posiadających rozbudowane księgozbiory - hasło nie jest szczegółowe, ale oddaje treść książki, w przypadku bibliotek o skromnym księgozbiorze nie jest jednak wystarczające.

Dwie spośród 25 przebadanych bibliotek zadeklarowały w badaniu, że stosuja słowa kluczowe do opracowywania zbiorów. Gramatyka języka słów kluczowych (JSK) odwołuje się do reguł indeksowania współrzędnego, polegającego na charakteryzowaniu złożonej treści dokumentu przez koordynację współrzędnych niezależnych wyrażeń (słów kluczowych), dających się swobodnie zestawiać. Słownik JSK to uporządkowany alfabetycznie wykaz słów

8 J. Hys J.: Pojęcie pragmatyki w teorii języków informacyjno-wyszukiwawczych. „Przegląd Biblioteczny" 2009, z. 1, s. 48.

${ }^{9}$ A. Stanis: Język haseł przedmiotowych KABA. W: Opracowanie przedmiotowe - osiągnięcia naukowe i praktyka. Warsztaty: 31.03-1.04.2004. Warszawa 2004, s. 31. 
kluczowych ${ }^{10}$. Analiza opisów dokumentów w katalogach obu bibliotek, które deklarowały stosowanie JSK, dowodzi jednak, iż nie jest to ten język.

Przykład opracowania publikacji przez jedną z bibliotek PWSZ deklarujących stosowanie JSK:

Krajoznawstwo: zarys teorii i metodyki / Zygmunt Kruczek, Artur Kurek, Marek Nowacki Kraków: Wydaw. PROKSENIA, 2003.

KRAJOZNAWSTWO - pojęcie - rozwój w Polsce - formy i kierunki działalności - metodyka organizowania i programowania IMPREZA TURYSTYCZNA - programowanie - metodyka prowadzenia DZIEDZICTWO - pojęcie - interpretacja.

Jak widać, mamy tu do czynienia raczej z JHP stworzonym na potrzeby określonej biblioteki, a nie z językiem słów kluczowych. Przeszukując katalog OPAC drugiej biblioteki, która zgłosiła stosowanie JSK, znaleziono następujący opis powyższego tytułu:

Krajoznawstwo: zarys teorii i metodyki / Zygmunt Kruczek, Artur Kurek, Marek Nowacki. Kraków: Wydaw. PROKSENIA, 2003

TURYSTYKA - aspekt społeczny - podręczniki.

KRAJOBRAZ - ocena - podręczniki.

EKOLOGIA CZŁOWIEKA - aspekt społeczny - podręczniki.

GEOGRAFIA.

Forma prezentacji sugeruje, że do opisu rzeczowego wykorzystano jakiś język haseł przedmiotowych, zaś użycie określnika aspekt społeczny może sugerować, że tym językiem jest JHP KABA.

W omawianym badaniu przeanalizowano również sposoby opracowania publikacji ksiaż̇kowych w katalogach OPAC bibliotek PWSZ. Dokonano analizy opisów rzeczowych dwóch publikacji zwartych:

Kompendium pilota wycieczek / pod red. Zygmunta Kruczka. - Kraków: Wydaw. PROKSENIA, 2005

oraz

Obsługa ruchu turystycznego: praca zbiorowa / pod red. Zygmunta Kruczka; [aut. Andrzej Fitrzyk i in.]. - Kraków: Krakowska Szkoła Hotelarska, 2006.

Uwzględniono przy tym propozycje haseł przedmiotowych Centrum NUKAT i Biblioteki Narodowej przedstawione w tabeli 2.

10 Z. Żmigrodzki, W. Babik, D. Pietruch-Reizes: Informacja naukowa: rozwój-metody - organizacja. Warszawa 2006, s. 210. 
Hasła przedmiotowe i słowa kluczowe Centrum NUKAT i Biblioteki Narodowej

\begin{tabular}{|l|l|l|}
\hline \multicolumn{1}{|c|}{ Publikacja } & \multicolumn{1}{|c|}{$\begin{array}{c}\text { Hasła przedmiotowe } \\
\text { Centrum NUKAT }\end{array}$} & \multicolumn{1}{|c|}{$\begin{array}{c}\text { Hasła przedmiotowe } \\
\text { Biblioteki Narodowej }\end{array}$} \\
\hline $\begin{array}{l}\text { Kompendium pilota wycieczek } \\
\text { / pod red. Zygmunta Krucz- } \\
\text { ka. - Kraków: Wydaw. } \\
\text { PROKSENIA, 2005 }\end{array}$ & $\begin{array}{l}\text { JHP KABA Podróże zorgani- } \\
\text { zowane - podręczniki } \\
\text { Turystyka - poradniki }\end{array}$ & $\begin{array}{l}\text { JHP BN } \\
\text { brak tytułu w katalogu BN }\end{array}$ \\
\hline $\begin{array}{l}\text { Obsługa ruchu turystycznego: } \\
\text { praca zbiorowa / pod red. }\end{array}$ & $\begin{array}{l}\text { JHP KABA } \\
\text { Zygmunta Kruczka; [aut. } \\
\begin{array}{l}\text { Andrzej Fitrzyk i in.]. - } \\
\text { Kraków: Krakowska Szkoła } \\
\text { Hotelarska, 2006 }\end{array}\end{array}$ & $\begin{array}{l}\text { JHP BN (Biblioteka Narodowa) } \\
\text { Turystyka - organizacja } \\
\text { Podręczniki }\end{array}$ \\
\hline
\end{tabular}

Ponieważ w katalogu BN nie znaleziono opisu książki Kompendium pilota wycieczek, autorka samodzielnie przygotowała jej opis w JHP BN, który, jej zdaniem, powinien składać się z dwóch haseł przedmiotowych:

\section{Wycieczki - organizacja \\ Piloci wycieczek}

Opis Kompendium pilota wycieczek odnaleziono w 10 katalogach OPAC bibliotek PWSZ. Jedna z nich zadeklarowała stosowanie JSK, jedna JHP KABA, pozostałe osiem stosuje JHP BN. Sposoby opracowania pozycji zaprezentowano $w$ tabeli 3.

Tabela 3

Opisy rzeczowe książki Kompendium pilota wycieczek / pod red. Zygmunta Kruczka. Kraków: Wydaw. PROKSENIA 2005 w katalogach OPAC bibliotek PWSZ

\begin{tabular}{|c|c|c|}
\hline JSK & JHP BN & JHP KABA \\
\hline \multirow{8}{*}{$\begin{array}{l}\text { Turystyka - pilotaż wycieczek } \\
\text { - przemysł turystyczny } \\
\text { Pilotaż wycieczek }\end{array}$} & $\begin{array}{l}\text { Wycieczki - organizacja } \\
\text { Piloci wycieczek }\end{array}$ & \multirow{8}{*}{$\begin{array}{l}\text { Przewodnicy turystyczni - } \\
\text { podręczniki } \\
\text { Turystyka - przewodnik }\end{array}$} \\
\hline & Piloci wycieczek - podręcznik & \\
\hline & $\begin{array}{l}\text { Przewodnictwo turystyczne - } \\
\text { podręcznik } \\
\text { Turystyka - Polska } \\
\text { Pilot a grupa } \\
\text { Turystyka - psychologia } \\
\text { Turystyka - BHP } \\
\text { Turystyka }\end{array}$ & \\
\hline & Turystyka - podręcznik akademicki & \\
\hline & $\begin{array}{l}\text { Podróże zorganizowane - podręcznik } \\
\text { Turystyka - poradnik } \\
\text { Turystyka - pilotaż wycieczek - } \\
\text { obsługa } \\
\text { Turystyka - psychologia }\end{array}$ & \\
\hline & $\begin{array}{l}\text { Turystyka - podręcznik akademicki } \\
\text { Piloci wycieczek - podręcznik }\end{array}$ & \\
\hline & $\begin{array}{l}\text { Turystyka } \\
\text { Wycieczki - organizacja }\end{array}$ & \\
\hline & $\begin{array}{l}\text { Piloci wycieczek - podręcznik } \\
\text { Wycieczki - organizacja }\end{array}$ & \\
\hline
\end{tabular}


Obsługe ruchu turystycznego odnaleziono również w 10 z 25 przebadanych katalogów OPAC bibliotek PWSZ. W tym przypadku dwie biblioteki potwierdziły wykorzystywanie JSK, jedna JHP KABA, siedem JHP BN. Zastosowane przez nie hasła przedmiotowe i słowa kluczowe zamieszczono w tabeli 4.

Tabela 4

Opisy rzeczowe książki Obsługa ruchu turystycznego: praca zbiorowa / pod red. Zygmunta Kruczka; [aut. Andrzej Fitrzyk i in.]. - Kraków: Krakowska Szkoła Hotelarska 2006 w katalogach OPAC bibliotek PWSZ

\begin{tabular}{|c|c|c|}
\hline JSK & JHP BN & JHP KABA \\
\hline $\begin{array}{l}\text { Ruch turystyczny - obsługa } \\
\text { Turystyka - obsługa ruchu } \\
\text { turystycznego }\end{array}$ & $\begin{array}{l}\text { Piloci wycieczek } \\
\text { Wycieczki - organizacja } \\
\text { Hotelarstwo } \\
\text { Przewodnictwo turystyczne } \\
\text { Turystyka - obsługa } \\
\text { Schroniska turystyczne }\end{array}$ & \multirow[t]{7}{*}{ Turystyka - obsługa klientów } \\
\hline $\begin{array}{l}\text { Turystyka - podręczniki } \\
\text { Obsługa klientów } \\
\text { Zarządzanie }\end{array}$ & $\begin{array}{l}\text { Turystyka - organizacja - } \\
\text { podręcznik akademicki }\end{array}$ & \\
\hline & $\begin{array}{l}\text { Turystyka - transport pasażerski } \\
\text { Turystyka - organizacja } \\
\text { Turystyka - prawo } \\
\text { Turystyka }\end{array}$ & \\
\hline & $\begin{array}{l}\text { Turystyka - organizacja - } \\
\text { podręcznik } \\
\text { Turystyka - ekonomika - } \\
\text { podręcznik } \\
\text { Usługi - turystyka - podręcznik }\end{array}$ & \\
\hline & $\begin{array}{l}\text { Ruch turystyczny } \\
\text { Biura podróży } \\
\text { Ubezpieczenia - turystyka } \\
\text { Turystyka - organizacja - } \\
\text { podręcznik }\end{array}$ & \\
\hline & Turystyka & \\
\hline & $\begin{array}{l}\text { Turystyka - organizacja - } \\
\text { podręcznik akademicki }\end{array}$ & \\
\hline
\end{tabular}

Przykłady opisów publikacji Kompendium pilota wycieczek i Obsługi ruchu turystycznego przedstawione w tabelach 2 i 3 pokazuja, iż mimo zastosowania takiego samego JIW charakterystyki treściowe dokumentów są zróżnicowane.

Biblioteki neofilologiczne dużych ośrodków akademickich są bibliotekami wydziałowymi, posiadaja własne katalogi, w których zbiory otrzymuja hasła przedmiotowe wyrażone w języku polskim i w językach obcych. W większości PWSZ funkcjonują kierunki filologiczne. Biblioteki tych jednostek rzadko posiadają odrębne katalogi, zbiory obcojęzyczne są opracowywane w JHP wyrażanym w języku polskim, co utrudnia studentom wyszukiwanie pożądanych informacji.

\section{Przykład opracowania pozycji obcojęzycznej przez jedną z bibliotek PWSZ}

How to Teach Writing / Jeremy Harmer. - Harlow: Longman, 2008 Język angielski - język pisany - studia i nauczanie 
Język angielski - studia i nauczanie - obcojęzyczni

English language - Study and teaching - Foreign speakers

English language - Written English - Study and teaching

English language teaching - Writing.

Na pytanie sondażowe dotyczące stosowania JIW biblioteka odpowiedziała, że korzysta z JHP BN. Okazuje się jednak, że tworzone przez nią hasła przedmiotowe nie w pełni odpowiadaja metodyce tego języka. JHP BN jest wyrażany w języku polskim, w powyższym przypadku bibliotekarze zastosowali dodatkowe hasła wyrażone w języku obcym. W innych bibliotekach PWSZ deklarujących stosowanie JHP BN publikacja ta otrzymywała hasło: Język angielski - nauczanie.

Opisy niewielu publikacji niezbędnych do nauczania na kierunkach neofilologicznych można znaleźć w katalogu Biblioteki Narodowej. Biblioteki PWSZ stosujące JHP BN mają więc utrudnione zadanie, indeksowanie zbiorów obcojęzycznych wymaga samodzielnego tworzenia haseł zgodnie z metodyka JHP BN. Dużym ułatwieniem dla użytkownika byłoby stosowanie dodatkowych haseł sformułowanych w języku obcym. Do takich haseł można dotrzeć poprzez JHP KABA, Biblioteka Narodowa nie tworzy haseł wyrażonych w języku obcym.

\section{Opracowanie zbioru informacyjnego biblioteki Państwowej Szkoły Wyższej im. Papieża Jana Pawła II w Białej Podlaskiej}

Biblioteka PSW im. Papieża Jana Pawła II w Białej Podlaskiej posiada w swoich zbiorach ponad 20000 jednostek inwentarzowych. Opisy dokumentów opracowywanych w JHP BN umieszczane są w katalogu OPAC systemu SOWA i stanowią zbiór wyszukiwawczy, w którym czytelnicy wyszukują informacje.

Użytkownicy biblioteki PSW w Białej Podlaskiej umiejętności informacyjne zdobywaja podczas szkolenia prowadzonego w formie tradycyjnej przez bibliotekę uczelni oraz $w$ trakcie szkolenia $w$ formie online umieszczonego na stronie www biblioteki PSW. Zdarza się jednak, że maja problemy z wyszukiwaniem informacji, co zobrazuje sytuacja opisana poniżej. Użytkownik, w tym wypadku student, poszukiwanie danych na temat etycznych aspektów usuwania ciąży rozpoczął od katalogu OPAC systemu SOWA, funkcjonującego w bibliotece uczelnianej. Użył klucza wyszukiwawczego - „, hasło przedmiotowe”, wpisał słowo "aborcja” najczęściej kojarzące się z tą tematyka, rezultat wyszukiwania był jednak zerowy. Słownik JHP BN termin „aborcja” traktuje jako termin odrzucony, proponując w zamian wyrażenie „poronienie sztuczne”. Użytkownik powinien skorzystać z indeksu haseł przedmiotowych, gdzie stosowny odsyłacz poinformuje go o konieczności użycia innego hasła. Nie skorzystał z tej możliwości, nie zdobył zatem informacji na temat literatury traktującej o tym zagadnieniu. Czy można obarczyć go winą za zaistniałą sytuację, czy też zastanowić się nad JIW zastosowanym do opracowania zbiorów na ten temat?

Termin „poronienie sztuczne” okazał się mało znany użytkownikowi, podobnie jak termin „dychawica oskrzelowa” proponowany zamiast terminu „astma”. 
JHP BN nie najlepiej sprawdził się w katalogu przeszukiwanym przez użytkownika końcowego, przyzwyczajonego do korzystania z wyszukiwarek internetowych i opisującego obiekty za pomocą tzw. tagów (swobodnych słów kluczowych).

\section{Propozycje zmian w sposobie opracowywania}

Biblioteka PSW w Białej Podlaskiej stara się odpowiadać na potrzeby swoich użytkowników i podnosić jakość świadczonych przez nią usług. Dane uzyskane z innych bibliotek PWSZ zostały przedstawione jej pracownikom do analizy. W kwietniu 2010 r. wśród pracowników biblioteki przeprowadzony został sondaż na temat preferowanego JIW, w którym powinny być opracowywane zbiory w jej katalogu podstawowym. $67 \%$ pracowników stwierdziło, iż powinno się stosować dwa JIW: trudniejszy JHP BN i przyjazny studentom JSK; 33\% pracowników opowiedziało się za stosowaniem tylko JHP BN. Biblioteka PSW korzysta z systemu SOWA 1, w którym stosuje się własny format danych, nie zaś format Marc 21. Format podstawowy nie daje użytkownikom możliwości wyszukiwania poprzez słowa kluczowe w poszczególnych indeksach. Użytkownicy biblioteki moga posługiwać się takimi słowami kluczowymi jak: autor, tytuł, hasło przedmiotowe, rok wydania, wydawca, sygnatura, uwagi, opis zawartości. Biblioteka PSW chciałaby zakupić pakiet SOWA2/MARC21 klient-serwer, pozwalający na wyszukiwanie poprzez słowa kluczowe w indeksach, nie jest to jednak możliwe ze względów finansowych (badania przeprowadzono w 2010 r., w lipcu 2011 r. przeprowadzono konwersję na format MARC 21 - środki pozyskano z projektu finansowanego z EFS).

W celu ułatwienia użytkownikom poszukiwania informacji w katalogu bibliotecznym podjęto decyzję o wprowadzeniu JSK jako dodatkowego JIW, który może być stosowany do opracowywania zbiorów o różnorodnej tematyce.

JSK ma prostszą strukturę niż JHP BN. Istotna różnica między nimi polega na statusie jednostek leksykalnych. JSK zawiera tylko jednostki autosyntaktyczne, które samodzielnie tworzą zdania. JHP BN zawiera w słownictwie jednostki synsyntaktyczne, niemogące samodzielnie występować, tzw. określniki, które dopiero w połączeniu z tematami (jednostkami autosyntaktycznymi) tworzą zdania. Jak już powiedziano, JSK jest mniej sformalizowany od JHP BN, jest także łatwiejszy do opanowania przez użytkowników, ale może być przyczyną szumu informacyjnego, tj. wydawania użytkownikom opisów dokumentów nierelewantnych w stosunku do pytania informacyjnego, stąd decyzja o dalszym wykorzystywaniu przez bibliotekę PSW w Białej Podlaskiej JHP BN, w którym słownictwo jest kontrolowane. Postanowiono także stosować indeksowanie w szerszym zakresie w oparciu o metodykę JHP BN, gdyż hasła przejmowane z Biblioteki Narodowej są niekiedy zbyt ogólne i pomijają tematy poboczne, istotne w zbiorze informacyjnym niewielkiej biblioteki. Plan strategiczny biblioteki PSW zakłada również w perspektywie (od 2013 roku) zmianę JHP BN na JHP KABA, który pozwoli zintegrować się z katalogami dużych bibliotek akademickich. 


\section{Wnioski}

Jakość opracowania rzeczowego zależy m.in. od prawidłowości doboru JIW do potrzeb systemu i jego użytkowników. Wypada mieć nadzieję, że działania biblioteki PSW w Białej Podlaskiej przyniosą oczekiwany rezultat: uzyskiwanie przez studentów jak największej ilości relewantnych odpowiedzi na stawiane przez nich zapytania, a przez to osiagnięcie satysfakcji i zadowolenia, które będą stanowić o sukcesie biblioteki.

\section{Bibliografia}

1. Babik W.: Słowa kluczowe. Kraków 2010.

2. Ball R.: Satysfakcja klienta jako kluczowy czynnik sukcesu biblioteki: działania Biblioteki Centralnej Forschungszentrum Jülich na rzecz użytkowników. „Przegląd Biblioteczny” 2009 , z. 1, s. 5-15.

3. Bojar B.: Języki informacyjno-wyszukiwawcze wczoraj, dziś... czy jutro? „Zagadnienia Informacji Naukowej" 2009, nr 1, s. 3-24.

4. Hys J.: Pojęcie pragmatyki w teorii języków informacyjno-wyszukiwawczych. „Przegląd Biblioteczny" 2009, z. 1, s. 41- 53.

5. MENiS: Wykaz Państwowych Wyższych Szkół Zawodowych. Ministerstwo Edukacji Narodowej i Sportu. [online]. [dostęp: 22.03.2010]. Dostępny w World Wide Web: <http:// www.nauka.gov.pl/szkolnictwo-wyzsze/system-szkolnictwa-wyzszego/uczelnie/uczelnie-publiczne/wykaz-uczelni-publicznych-nadzorowanych-przez-ministra-wlasciwego-dsszkolnictwa-wyzszego/panstwowe-wyzsze-szkoly-zawodowe>.

6. Sosińska-Kalata B.: Podręcznik UKD [Uniwersalnej Klasyfikacji Dziesiętnej] dla bibliotekarzy i pracowników informacji. Warszawa 1995.

7. Stanis A.: Język haseł przedmiotowych KABA. W: Opracowanie przedmiotowe - osiągnięcia naukowe i praktyka. Warsztaty: 31.03-1.04.2004. Warszawa 2004, s. 25-43.

8. Woźniak-Kasperek J.: Tendencje w teorii i praktyce języków informacyjno-wyszukiwawczych. W: Opracowanie przedmiotowe - osiągnięcia naukowe i praktyka. Warsztaty: 31.03-1.04.2004. Warszawa 2004, s. 3-25.

9. Woźniak-Kasperek J.: Języki informacyjne: między tradycją a nadzieją na cyfrową przyszłość. „Przegląd Biblioteczny” 2010, z. 1, s. 5-18.

10. Żmigrodzki Z., Babik., Pietruch-Reizes D.: Informacja naukowa: rozwój- metody - organizacja. Warszawa 2006.

\section{Summary}

Answering the users' needs is a reliable verification of quality of information-retrieval tools. The article presents results of the questionnaire survey concerning information retrieval-languages being used in libraries of public higher vocational schools. The author discusses examples of indexed documents, in particular from the Library of the John Paul II Public Higher Vocational School in Biała Podlaska. 